\title{
Electrodeposition of Metal Alloy and Mixed Oxide Films Using a Single-Precursor Tetranuclear Copper-Nickel Complex
}

\author{
Christopher E. Dubé, ${ }^{a}$ Bizuneh Workie, ${ }^{*}$ Samuel P. Kounaves, ${ }^{* *}$ Albert Robbat, Jr., and M. Levant Aksu \\ Department of Chemistry, Tufts University, Medford, Massachusetts 02155, USA
}

Geoffrey Davies

Department of Chemistry, Northeastern University, Boston, Massachusetts 02115, USA

\begin{abstract}
Electroreduction of heterotetranuclear complexes $\left(\mu_{4}-\mathrm{O}\right) \mathrm{L}_{4} \mathrm{Cu}_{4-x} \mathrm{Ni}_{x}\left(\mathrm{H}_{2} \mathrm{O}\right)_{x} \mathrm{Cl}_{6}(x=1-4, L=N, N$-diethylnicotinamide) at a $\mathrm{Pt}$ electrode in dimethylsulfoxide leads to deposition of $\mathrm{Cu}-\mathrm{Ni}$ alloys with codeposition of $\mathrm{Cu}$ (I) oxide, Ni(II) oxide, and Ni(II) hydroxide. The alloy deposition potential is invariant with complex stoichiometry. Alloy Ni composition, determined by x-ray diffraction (XRD), increases from $12 \%$ for $x=1$ to $62 \%$ for $x=4$. The microscopically rough, well-adhering, continuous films have a natural passivation layer formed by air oxidation that consists of $\mathrm{Ni}(\mathrm{OH})_{2}, \mathrm{NiO}, \mathrm{Cu}(\mathrm{OH})_{2}$, and $\mathrm{Cu} 2 \mathrm{O}$. $\mathrm{X}$-ray photoelectron spectroscopy confirmed the bulk film alloy compositions obtained by XRD. The data revealed complex deposit structures consisting of $\mathrm{NiO}, \mathrm{Ni}(\mathrm{OH})_{2}, \mathrm{Cu}_{2} \mathrm{O}$, and $\mathrm{Cu}-\mathrm{Ni}$ alloy giving a mass balance of the metals in the complexes. The $\mathrm{Cu}_{2} \mathrm{O} / \mathrm{Cu}^{0}$ ratio is close to unity for the deposit made from the $\mathrm{Cu}_{4}$ complex and decreases to zero for the $\mathrm{CuNi}_{3}$ complex. In contrast only half of the $\mathrm{Ni}$ (II) centers are deposited as $\mathrm{Ni}^{0}$ in the Cu-Ni alloy, the balance consisting of $37 \% \mathrm{NiO}$ and $15 \% \mathrm{Ni}(\mathrm{OH})_{2}$. The constant percentage of $\mathrm{Ni}$ as $\mathrm{Ni}(\mathrm{OH})_{2}$ in all deposits suggests that it arises from reduction of $\mathrm{Ni}$ coordinated water. Mass balance indicates $\mathrm{O}$ in $\mathrm{Cu}_{2} \mathrm{O}$ and $\mathrm{NiO}$ originates from the $\mu_{4}-\mathrm{O}$. Smooth variations of alloy compositions, metal oxide/metal ratios, and film particle sizes indicate that all the electrode processes involve discrete molecules of the heteropolymetallic complex.
\end{abstract}

\section{Introduction}

Compositionally uniform mixed metals, metal oxides, and alloys are used extensively as corrosion protective coatings, nanostructurally designed materials with unique mechanical and electronic properties and catalysts. ${ }^{1-5}$ For example, nickel-containing oxides and alloys are used for oxidative protection of very fine ferromagnetic iron particles in various types of magnetic recording media (e.g., hard disks) and in the manufacture of memory and other microelectronic devices. Polymetallic catalysts are used in the chemical and petroleum industries for organic hydrogenation, reforming of naphthas, catalytic hydroconversion, methanol oxidation, and coal liquefaction. ${ }^{1,2}$ The synthesis of bimetallic alloys and oxides is much more challenging than that of pure metals, especially if low temperatures are necessary to prevent sintering. Although supports or "structure promoters" can slow sintering, control of the uniform distribution of different metallic elements on a support is difficult to achieve.

$\mathrm{Cu}-\mathrm{Ni}$ alloys and their oxides are well-known catalysts for some useful chemical processes ${ }^{1,2,5}$ and have superior corrosion properties when compared to the parent metals. ${ }^{3,4}$ Although the formation of ductile homogeneous $\mathrm{Cu}-\mathrm{Ni}$ alloys by metallurgical techniques is well established, electrodeposition of these alloys is complicated by a nearly $600 \mathrm{mV}$ difference in the standard reduction potentials of aquo $\mathrm{Cu}(\mathrm{II})$ and $\mathrm{Ni}$ (II). A greater difference often leads to preferred deposition of the metal with the more positive reduction potential and exclusion of the less noble metal. Complexing ligands can be used to bring the deposition potentials of two metals closer together, leading to codeposition. Citrate and pyrophosphate ligands have shown the most promise for codeposition of $\mathrm{Cu}-\mathrm{Ni}$ alloy. ${ }^{3,6}$ The use of cyanide,${ }^{7}$ tartrate, ${ }^{8}$ glycine,${ }^{9}$ and L-asparagine, ${ }^{10}$ have been described. Although $\mathrm{Cu}-\mathrm{Ni}$ alloy deposition has been studied for many years, none of the previous approaches has led to a commercially viable process. Controllable deposition of $\mathrm{Cu}-\mathrm{Ni}$ alloy films still remains at the forefront of research in alloy electrodeposition. ${ }^{11-14}$

* Electrochemical Society Student Member.

** Electrochemical Society Active Member.

a Present address: Department of Chemistry, Boston College, Boston, MA 02167, USA.

${ }^{b}$ Present address: Department of Chemistry, University of Gazi, Ankara, Turkey
The tetranuclear copper(II) complexes $\left(\mu_{4}-\mathrm{O}\right) \mathrm{L}_{4} \mathrm{Cu}_{4} \mathrm{Cl}_{6}$, with $\mathrm{L}$ typically being a pyridine derivative, have been reported in the literature since the mid-60s. ${ }^{15-17}$ Their structures, ${ }^{16,18-21}$ spectrochemical, ${ }^{22-25}$ thermal, ${ }^{26}$ and magnetic ${ }^{22,23}$ behaviors have been subjected to extensive investigation. Structurally these complexes consist of four $\mathrm{Cu}$ atoms of distorted trigonal bipyramidal geometry, each bridged to the central tetrahedral oxygen, three $\mathrm{Cl}$ atoms, and an organic ligand. These complexes have the unique property that the $\mathrm{Cu}$ atoms can be successively and stoichiometrically replaced (transmetallated) with other metal atoms such as $\mathrm{Ni}, \mathrm{Zn}, \mathrm{Co}$, without altering the geometry of the complex, to give a series of heteropolymetallic complexes (HPMC). ${ }^{27-32}$ Previous work has shown that these $\mathrm{Cu}-\mathrm{Ni}$ complexes can be thermolytically deposited to give Cu-Ni alloy films. ${ }^{33}$

Our recent work ${ }^{34-37}$ has shown that the series of tetranuclear copper-nickel complexes $\left(\mu_{4}-\mathrm{O}\right) \mathrm{L}_{4} \mathrm{Cu}_{4-x} \mathrm{Ni}_{x}\left(\mathrm{H}_{2} \mathrm{O}\right)_{x} \mathrm{Cl}_{6}$ with $x=0-4$ and $\mathrm{L}=N, N$, -diethylnicotinamide (denc) and other pyridine-derived ligands, dissolved in organic solvents such as dimethylsulfoxide (DMSO) with $0.20 \mathrm{M}$ tetrabutylammonium hexafluorophosphate (TBAHFP) as electrolyte, can be used as single-source (unimolecular) precursors to electrochemically deposit $\mathrm{Cu}-\mathrm{Ni}$ alloy and oxide films whose net deposition stoichiometry is controlled by the metal stoichiometry of the precursor.

We characterize the $\mathrm{Cu}-\mathrm{Ni}$ films, produced by this novel electrodeposition process, using $\mathrm{x}$-ray diffractometry (XRD), scanning electron microscopy (SEM), energy dispersive x-ray spectroscopy (EDS), and x-ray photoelectron spectroscopy (XPS). We propose a tentative model for $\mathrm{Cu}-$ $\mathrm{Ni}$ alloy formation via normal deposition of copper and nickel with codeposition of $\mathrm{NiO}, \mathrm{Ni}(\mathrm{OH})_{2}$, and $\mathrm{Cu}_{2} \mathrm{O}$ involving a water molecule coordinated to each nickel center and the $\mu_{4}$-oxygen centrally coordinated to copper and nickel in $\left(\mu_{4}-\mathrm{O}\right)$ (denc) ${ }_{4} \mathrm{Cu}_{4-x} \mathrm{Ni}_{x}\left(\mathrm{H}_{2} \mathrm{O}\right)_{x} \mathrm{Cl}_{6}$. The potential necessary for alloy deposition is essentially invariant with complex stoichiometry. Copper and nickel are distributed between the alloy and the above oxides after reduction of the complex at the electrode surface.

This controlled unimolecular electrodeposition technique may hold the key to producing new types of alloy and metal oxide films with specific predefined stoichiometries and new types of metal alloy and oxide catalysts and coatings. This process could be of importance in environmental considerations. The plating industry has been a conspicu- 
ous contributor to environmental pollution (especially surface and groundwater). Currently, little motivation or technology exists to reduce or recycle the complex mixtures of acid and/or cyanide baths loaded with metals, organics, and inorganic salts. A new approach, designed with the concept of a single carrier molecule in a simple solvent system such as DMSO, could eliminate highly contaminated discharge waters to the environment and result in a closed-loop manufacturing process and a savings in energy costs by recycling the solvent/electrolyte systems and thus significantly reducing the generation of waste over current practices.

\section{Experimental}

Complex synthesis. - The heterotetranuclear complexes for electrodeposition were synthesized in methylene chloride by transmetallation according to

$\left(\mu_{4}-\mathrm{O}\right) \mathrm{L}_{4} \mathrm{Cu}_{4} \mathrm{Cl}_{6}+x \mathrm{Ni}(\mathrm{NS})_{2}$

$$
\rightarrow\left(\mu_{4}-\mathrm{O}\right) \mathrm{L}_{4} \mathrm{Cu}_{4-x} \mathrm{Ni}_{x}\left(\mathrm{H}_{2} \mathrm{O}\right)_{x} \mathrm{Cl}_{6}+x \mathrm{Cu}(\mathrm{NS})_{2}
$$

where NS = S-methyl isopropylidenehydrazinecarbodithioate, $\mathrm{L}$ is denc, and $x=1,2,3$, or $4 .{ }^{24,27-29}$ Here Ni(NS) is the transmetallator and $\left(\mu_{4}-\mathrm{O}\right) \mathrm{L}_{4} \mathrm{Cu}_{4} \mathrm{Cl}_{6}$ is the tetranuclear transmetallation target molecule. The $\mathrm{H}_{2} \mathrm{O}$ molecule shown in Eq. 1 is coordinated to each new nickel center during chromatographic product separation and purification. ${ }^{32}$ We synthesized three heterotetranuclear complexes and two homotetranuclear complexes with the general formula $\left(\mu_{4}-\mathrm{O}\right)$ (denc) ${ }_{4} \mathrm{Cu}_{4-x} \mathrm{Ni}_{x}\left(\mathrm{H}_{2} \mathrm{O}\right)_{x} \mathrm{Cl}_{6}$ where $x=0-4$. The metal stoichiometry of each isolated complex was confirmed by atomic absorption analysis.

Electrodeposition.-The electrochemical cell was a three-electrode system consisting of an $\mathrm{Ag} / 0.01 \mathrm{M} \mathrm{AgPF}_{6} /$ $\mathrm{CH}_{3} \mathrm{CN}$ reference electrode, a platinum counterelectrode, and a $1.1 \mathrm{~cm}$ diam rotating disk electrode (RDE, Pine Instrument Co.). A PAR Model 273 potentiostat (EG\&G Instruments, Princeton NJ) was used to apply deposition potentials. Effects of solvent, rotation rate, working electrode material, and potential, in addition to results from previous studies, were considered in identifying optimum deposition conditions. DIMSO (Aldrich Sure-Seal, anhydrous) was identified as the optimum solvent. It allows good complex solubility, a wide electroinactive range and has low volatility. Unless otherwise noted, $0.2 M$ TBAHFP was used as the supporting electrolyte.

Fresh $1.0 \mathrm{mM}$ solutions of each complex in DMSO.were prepared prior to deposition. The electrochemical cell, containing approximately $10 \mathrm{ml}$ of solution, was degassed for 20 min with $\mathrm{N}_{2}$ and a blanket of $\mathrm{N}_{2}$ was maintained over the solution during deposition. Electrode preparation consisted of polishing with $0.05 \mu \mathrm{m}$ alumina slurry, ultrasonic cleaning in deionized water, rinsing with acetone and methanol, and drying. The general potential region for deposition was determined from the cyclic ${ }^{37}$ and hydrodynamic steady-state voltammograms. However, the precise deposition potential and rotation rate for any particular experiment were determined from the current density during deposition and whether the subsequent films were well adhered. Depositions in the range -2.0 to $-2.2 \mathrm{~V}$ vs. Ag/ $\mathrm{AgPF}_{6} / \mathrm{CH}_{3} \mathrm{CN}$ at $1600 \mathrm{rpm}$ gave a current density of approximately $2.0 \mathrm{~mA} / \mathrm{cm}^{2}$. Depositions for $1 \mathrm{~h}$ produced uniform 1-2 $\mu \mathrm{m}$ thick films covering the entire electrode surface. Our adherence test for the films involved withstanding a light wiping with a lab wipe during removal of residual electrolyte with fresh DMSO followed by washing with methanol and $\mathrm{N}_{2}$ drying. Films that survived this test were characterized by XRD, EDS, and XPS measurements and then subjected to polishing with $0.05 \mu \mathrm{m}$ alumina. Most of the films that survived the lab wipe test also withstood polishing to yield a metallic low luster surface. Only the electrodeposit from $\left(\mu_{4}-\mathrm{O}\right)(\text { denc })_{4} \mathrm{Ni}_{4}\left(\mathrm{H}_{2} \mathrm{O}\right)_{4} \mathrm{Cl}_{6}$ could not be uniformly polished.

$X R D$. - Analysis of the deposited films began with XRD over a $2 \theta$ range of $5^{\circ}$ to $95^{\circ}$ using a Nicolet I2/V-2000 dif- fractometer with $\mathrm{Cu}-\mathrm{K}_{\mathrm{\alpha}_{1.2}}$ radiation operated at $40 \mathrm{kV}$ and $30 \mathrm{~mA}$. The extent of alloy formation and composition were determined by indexing the alloy $2 \theta$ peak positions with the Pt electrode peaks as an internal standard. The $\mathrm{Cu}-\mathrm{Ni}$ system forms a continuous solid solution alloy but the lattice parameters deviate from Vegard's law. We determined the alloy composition with an experimentally determined relationship between lattice parameter and composition ${ }^{38}$ which was verified with a $\mathrm{Cu}_{58}{ }_{2} \mathrm{Ni}_{41.8}$ [atomic percent (a/o)] metallurgical alloy standard (Alfa Products; composition confirmed by ICP atomic emission spectroscopy). XRD analysis using $\mathrm{Coles}^{38}$ lattice parameter data gave a composition of $\mathrm{Cu}_{57.9} \mathrm{Ni}_{42.1}$ for the standard.

The full-width half-maximum (FWHM) of the (111) reflection of the alloys was used to estimate the alloy average particle size using the Scherrer equation..$^{39}$ Correction for instrumental broadening of XRD peaks of known polycrystalline silicon and platinum standards was applied in determining linewidth broadening due to the particle size of the deposited alloys. Although we have analyzed this broadening in terms of alloy particle size, disorder and lattice strain in the alloy could also contribute to it. ${ }^{39^{\prime}}$ In addition to the reflections associated with the $\mathrm{Cu}-\mathrm{Ni}$ alloy products, we observed three other sets of reflections belonging to a cubic lattice discussed below.

Our attempts to quantitate strain and particle size contributions to line broadening using an isotropic strain model ${ }^{39,40}$ were unsuccessful due to relatively low resolution of the $\mathrm{x}$-ray lines. Since electrodeposited alloys are known to be highly strained, it is expected that x-ray line broadening due to lattice strain represents a significant contribution to the overall line broadening measured for these films. Hence, the average particle sizes reported here represent a lower limit of the actual particle sizes.

$E D S .-B u l k$ elemental analyses of deposited films were made by EDS with a JEOL 6400 SEM equipped with a beryllium window and lithium-drifted silicon detector (Kevex/Fisons). Quantitative standardless analyses (ZAF correction) were conducted with Kevex/Fisons software. A typical analysis was performed at a beam energy of $20 \mathrm{kV}$ and a beam current of $100 \mathrm{pA}$ using either a large area raster of $2500 \mu \mathrm{m}^{2}$ or spot mode $\left(0.2 \mu \mathrm{m}^{2}\right)$. Spatial resolution for EDS analysis was limited by electron beam spreading in the sample of the order of $1.5 \mu \mathrm{m}$ at $20 \mathrm{kV}$. Standardless EDS analysis of the Cu-Ni alloy standard gave $59.4 \pm$ $3.1 \%$ copper and $40.6 \pm 3.1 \%$ nickel. The surface morphology of the deposited films was examined using both the secondary and backscatter modes of the SEM.

$X P S$-S Surface and depth profiling of $\mathrm{Cu}, \mathrm{Ni}$, and $\mathrm{O}$ in the deposited films together with information about the oxidation states of the elements and chemical environments were obtained by XPS with a Fisons Surface Science Model SSX100 spectrometer equipped with an $\mathrm{Ar}^{+}$gun, an Al- $\mathrm{K}_{\alpha 1,2}$ source, and a quartz monochromator. The concentric hemispherical analyzer was set with either a pass energy of $150 \mathrm{eV}$ for survey scans from $0-1000 \mathrm{eV}$, or $50 \mathrm{eV}$ for higher resolution scans for nickel, copper, and oxygen. A $600 \mu \mathrm{m}$ spot size was used for all analyses. The higher resolution $20 \mathrm{eV}$ scan widths of $\mathrm{Cu} 2 \mathrm{p}_{3 / 2}, \mathrm{Ni}_{2} \mathrm{p}_{3 / 2}, \mathrm{O} 1 \mathrm{~s}$, and the $\mathrm{Cu}\left(\mathrm{L}_{3} \mathrm{M}_{4,5} \mathrm{M}_{4.5}\right)$ Auger spectrum, were collected at 938, 858, 570 , and $536 \mathrm{eV}$ binding energies, respectively, Operating pressure was about $10^{-9}$ Torr and the detector takeoff angle was fixed at $36.5^{\circ}$. Binding energies were determined relative to the metallic copper $\left(\mathrm{Cu}^{0}\right) 2 \mathrm{p}_{3 / 2}$ binding energy of $932.4 \mathrm{eV}$, or to an adventitious carbon $\mathrm{C} 1 \mathrm{~s}$ binding energy of $285.0 \mathrm{eV}$ in the absence of copper. The position of the $\mathrm{Cu}^{0} 2 \mathrm{p}_{3 / 2}$ or $\mathrm{C} 1 \mathrm{~s}$ peak was used to correct for any shift in the experimental binding energies due to charging.

Chemical assignments to binding or kinetic energies were made on the basis of literature values and standards (see Tables I and II). Standards included polycrystalline nickel and copper metal (Alfa Products; 99.995\%), the 
Table I. XPS binding energies (eV).

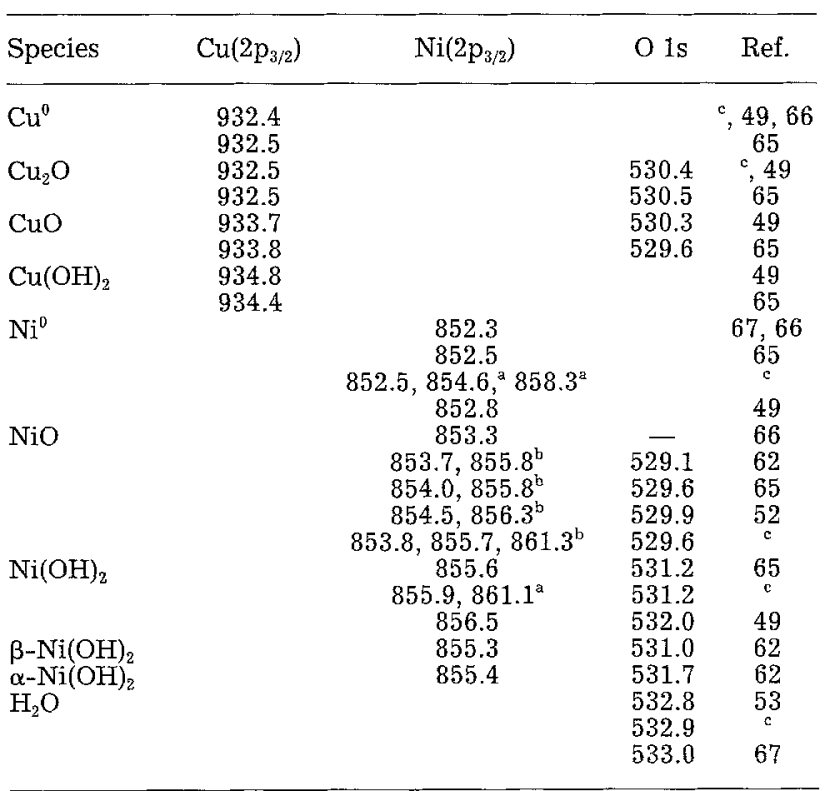

a Satellite (shake-up)

bultiplet splitting.

This work (using references described).

$\mathrm{Cu}_{58.2} \mathrm{Ni}_{41.8}$ metallurgical alloy, and $\mathrm{Cu}_{2} \mathrm{O}, \mathrm{NiO}$, and $\mathrm{Ni}(\mathrm{OH})_{2}$ powders (Aldrich; $\geq 97 \%$ ). The powders were pressed onto the surface of a platinum disk and the excess shaken off before mounting in the spectrometer. Binding energies were corrected for minor charging of the oxide samples by using the $\mathrm{C} 1 \mathrm{~s}$ line of adventitious carbon. The metallurgical alloy and the pure metals were mechanically polished with $0.05 \mu \mathrm{m}$ alumina, rinsed with water, acetone, methanol, and $\mathrm{N}_{2}$ dried, prior to loading in the spectrometer.

Curve fitting of the spectra was accomplished with Surface Science X-Probe ${ }^{\mathrm{TM}}$ software. Following background subtraction, using the literature procedure of Shirley, ${ }^{41}$ the peak envelopes were fitted using spectral lines defined according to the centroid position ( $E$, in $\mathrm{eV}$ ), half-width, peak shape (a combination of Gaussian and Lorentian distributions), and area signal intensity ( $I$, in counts). A single peak was used to fit each species in the O1s spectrum. The $\mathrm{Cu} 2 \mathrm{p}_{3 / 2}$ spectra of metallic copper and $\mathrm{Cu}_{2} \mathrm{O}$ standards, and $\mathrm{Ni} 2 \mathrm{p}_{3 / 2}$ spectra of metallic nickel $\left(\mathrm{Ni}^{0}\right), \mathrm{NiO}$, and $\mathrm{Ni}(\mathrm{OH})_{2}$ required multiple peaks because of the presence of electron shake-up and multiplet peaks.

For $\mathrm{Cu}_{2} \mathrm{O}$, the $\mathrm{Cu} 2 \mathrm{p}_{3 / 2}$ photoelectron spectrum is identical within $\pm 0.1 \mathrm{eV}$ to that for elemental copper. However, the x-ray induced Auger spectra of, $\mathrm{Cu}^{0}$ and $\mathrm{Cu}_{2} \mathrm{O}$ $\left[\mathrm{Cu}\left(\mathrm{L}_{3} \mathrm{M}_{4,5} \mathrm{M}_{4,5}\right)\right]$ are significantly different and allow a quantitative characterization of the oxide and metal. ${ }^{42}$ Due to the absence of higher valence oxides in the electrodeposited films, the relative contributions of $\mathrm{Cu}_{2} \mathrm{O}$ and $\mathrm{Cu}^{\circ}$ to the $\mathrm{Cu}\left(\mathrm{L}_{3} \mathrm{M}_{4.5} \mathrm{M}_{4.5}\right)$ spectrum could be determined by deconvolution using $\mathrm{Cu}^{\circ}$ and $\mathrm{Cu}_{2} \mathrm{O}$ reference spectra (Table II). Energy, FWHM, and relative intensities of the four components of the reference spectra were used to guide the deconvolution process.

Quantitative analysis of the alloy composition of the deposited films was based on referencing to an alumina-polished sample of the $\mathrm{Cu}-\mathrm{Ni}$ metallurgical alloy. The $\mathrm{Cu} 2 \mathrm{p}_{3 / 2}$

Table II. $\mathrm{Cu}\left(\mathrm{L}_{3} \mathrm{M}_{4,5} \mathrm{M}_{4,5}\right) \times$-ray induced Auger kinetic energies.

\begin{tabular}{lcc}
\hline Species & Kinetic energy (eV) & Ref. \\
\hline $\mathrm{Cu}^{0}$ & $921.5,918.9,916.5,914.5$ & 42 \\
$\mathrm{Cu}_{2} \mathrm{O}$ & $921.5,918.7,916.5,914.0$ & a \\
& $921.8,919.2,916.8,912.8$ & 42 \\
\hline
\end{tabular}

a This work (using references described in text).

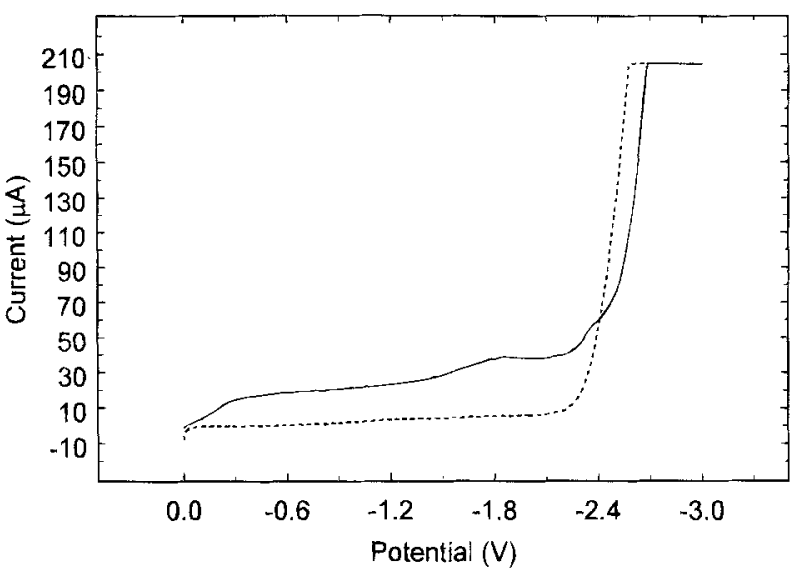

Fig. 1. Hydrodynamic RDE voltammograms for solutions of $0.1 \mathrm{M}$ TBAHFP in DMSO (---) and $1.0 \mathrm{mM}$ of $\left(\mu_{4} \text {-O) (denc) }\right)_{4} \mathrm{Cu}_{3} \mathrm{Ni}\left(\mathrm{H}_{2} \mathrm{O}\right) \mathrm{Cl}_{6}$ and $0.1 \mathrm{M}$ TBAHFP in DMSO diam of $1.1 \mathrm{~cm}$ and rotation rate of $1600 \mathrm{rpm}$, an $\mathrm{Ag} / \mathrm{AgPF}_{6}$ reference electrode and a Pt wire counferelectrode.

and $\mathrm{Ni} 2 \mathrm{p}_{3 / 2}$ spectra were fit over a 13 and $16 \mathrm{eV}$ spectral width, respectively, for both the metallurgical alloy and the electrodeposited films. A sensitivity factor for the $\mathrm{Cu}^{\%} /$ $\mathrm{Ni}^{0}$ ratio was determined from the signal intensity ratio $I_{\mathrm{Cu} 2 \mathrm{p}_{3 / 2}} / I_{\mathrm{N1} 2 \mathrm{p}_{3 / 2}}$ of the $\mathrm{Cu}_{58.2} \mathrm{Ni}_{41.8}$ metallurgical alloy. This sensitivity factor was applied to the intensity ratio $I_{\mathrm{Cu}(a l l o y) 2 p_{3} / 2} /$ $I_{\mathrm{Ni}(a l l o y) 2 p_{3 / 2}}$ of the electrodeposited films to arrive at the alloy composition. The use of $\mathrm{Cu}-\mathrm{Ni}$ alloy as a calibration standard has been questioned by some ${ }^{43.44}$ yet verified by others. ${ }^{45}$ We feel that this procedure minimizes experimental uncertainty in quantifying the composition of the films by XPS.

Since quantitative XPS analysis is known to be affected by surface roughness, ${ }^{46}$ we restrict our discussion to alumina-polished films. The only exception to this is for the film deposited from $\left(\mu_{4}-\mathrm{O}\right)(\text { denc })_{4} \mathrm{Ni}_{4}\left(\mathrm{H}_{2} \mathrm{O}\right)_{4} \mathrm{Cl}_{8}$ which was analyzed without polishing. To compare bulk and surface film compositions, all samples were $\mathrm{Ar}^{+}$sputtered at $3 \mathrm{kV}$ to remove the native passivation layer. A sputtering removal rate of $1 \AA / \mathrm{s}$ was assumed for all depth profiling experiments.

\section{Results}

Figure 1 illlustrates a typical RDE voltammogram for solutions containing $1.0 \mathrm{mM}$ of $\left(\mu_{4}-\mathrm{O}\right)$ (denc) ${ }_{4} \mathrm{Cu}_{3} \mathrm{Ni}\left(\mathrm{H}_{2} \mathrm{O}\right) \mathrm{Cl}_{6}$ and/or $0.1 M$ TBAHFP in DMSO; scan rate of $50 \mathrm{mV} / \mathrm{s}$; electrode diam of $1.1 \mathrm{~cm}$ and rotation rate of $1600 \mathrm{rpm}$. Figure 2 shows the SEM micrograph of the resulting $\mathrm{Cu}_{3} \mathrm{Ni}$ deposit morphology for the same solution after $1 \mathrm{~h}$ reduction at a constant potential of $-2.2 \mathrm{~V}$. The deposited mate-

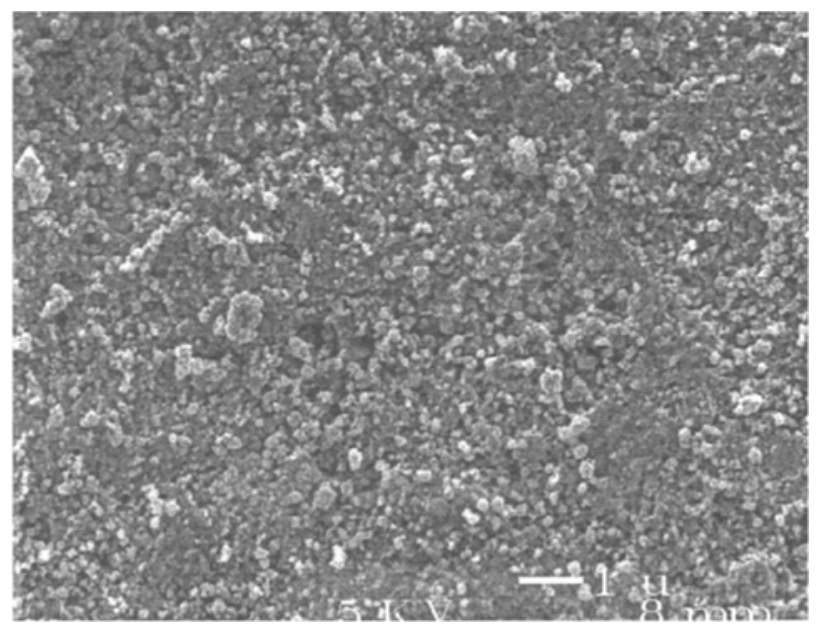

Fig. 2. SEM micrograph of the deposition made using the same solution as Fig. 1 after $1 \mathrm{~h}$ reduction at a constant potential of $-2.2 \mathrm{~V}$. 


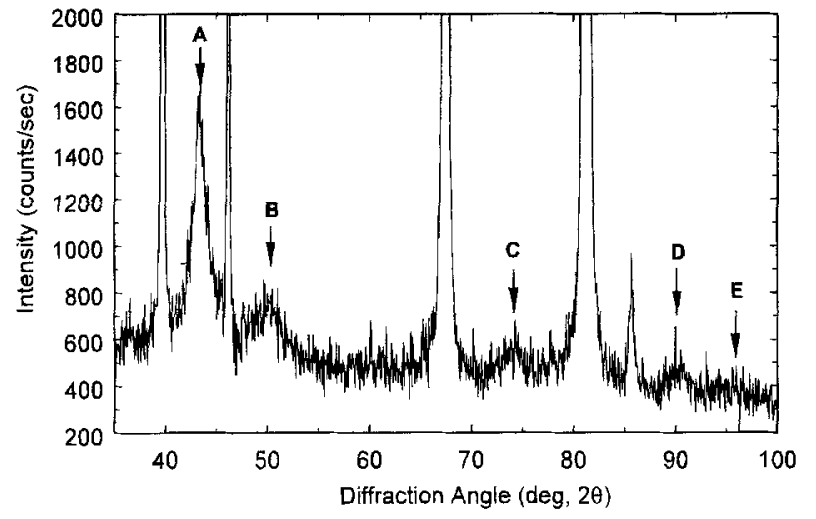

Fig. 3. XRD pattern of the sample shown in Fig. 2 with peaks A-E due to the Cu-Ni alloy lattice.

rial produced a reddish brown film that was continuous and well adhered. Elemental mapping by EDS showed spatially homogeneous copper $(65 \%)$ and nickel $(18 \%)$ as well as oxygen $(15 \%)$ and sulfur $(2 \%)$. The sulfur most likely is due to entrained DMSO. Normalizing the metals to $100 \%$ gave a film composition of $78 \%$ copper and $22 \%$ nickel.

The XRD pattern for a typical $\mathrm{Cu}_{3} \mathrm{Ni}$ deposit is shown in Fig. 3 with peaks $\mathrm{A}$ to $\mathrm{E}$ belonging to the $\mathrm{Cu}-\mathrm{Ni}$ alloy latice and the remaining to the $P t$ substrate. The absence of separate copper or nickel diffraction peaks signifies deposition of a single-phase $\mathrm{Cu}-\mathrm{Ni}$ alloy. However, least squares analysis of the alloy peaks of two $\mathrm{Cu}_{3} \mathrm{Ni}$ deposits gave an average lattice parameter, $a=3.603 \pm 0.005 \AA$, which corresponds to a $\mathrm{Cu}_{88 \pm 3} \mathrm{Ni}_{12 \pm 3}$ alloy composition. ${ }^{38}$ This differs from the anticipated composition of $\mathrm{Cu}_{75} \mathrm{Ni}_{25}$. Although EDS indicates the same total $\mathrm{Cu} / \mathrm{Ni}$ ratio in the deposit as in the precursor complex formula, the EDS and XRD results together indicate that less than half of the nickel in the film is alloyed with copper, with the remainder being deposited as nickel compounds.

EDS and XRD analysis of electrodeposits from the $\left(\mu_{4}-\right.$ O)(denc) $)_{4} \mathrm{Cu}_{2} \mathrm{Ni}_{2}\left(\mathrm{H}_{2} \mathrm{O}\right)_{2} \mathrm{Cl}_{6}$ and $\left(\mu_{4}-\mathrm{O}\right)$ (denc) $)_{4} \mathrm{CuNi}_{3}\left(\mathrm{H}_{2} \mathrm{O}\right)_{3} \mathrm{Cl}_{6}$ complexes revealed a similar pattern of behavior, namely, good agreement between complex metal stoichiometry and the total $\mathrm{Cu} / \mathrm{Ni}$ ratio in the film but lower nickel concentration in the alloy compared to the total nickel concentration in the film. EDS and XRD results for all five complexes of the series are given in Tables III and IV, respectively.

For the $\left(\mu_{4}-\mathrm{O}\right)(\text { denc })_{4} \mathrm{Ni}_{4}\left(\mathrm{H}_{2} \mathrm{O}\right)_{4} \mathrm{Cl}_{6}$ complex, EDS indicated that about $4 \%$ of the electrodeposited metal consisted of copper. These results were consistent with atomic absorption (AA) spectrophotometry of the initial gel-chromatographed complex used in the deposition experiment indicating that the transmetallation (Eq. 1, with $x=4$ ) had not gone to completion and that some of the copper-containing complex remained in solution after purification. Although gel permeation chromatography is efficient in separating the transmetallation products $\mathrm{Cu}(\mathrm{NS})_{2}$ and

Table III. Mass balance of electrodeposition."

\begin{tabular}{|c|c|c|c|c|c|c|c|}
\hline \multirow[b]{2}{*}{ Complex } & \multicolumn{2}{|c|}{$\operatorname{EDS}^{b}$} & \multicolumn{2}{|c|}{$\mathrm{Cu} 2 \mathrm{p}_{3 / 2}{ }^{\mathrm{c}}$} & \multicolumn{3}{|c|}{$\mathrm{Ni} 2 \mathrm{p}_{3 / 2}$} \\
\hline & $\% \mathrm{Cu}$ & $\% \mathrm{Ni}$ & $\% \mathrm{Cu}^{\circ}$ & $\% \mathrm{Cu}_{3} \mathrm{O}$ & $\% \mathrm{Ni}^{\circ}$ & $\% \mathrm{NiO}$ & $\% \mathrm{Ni}(\mathrm{OH})_{2}$ \\
\hline & 100 & 0 & 51 & 49 & - & - & - \\
\hline $\mathrm{Cu}_{3} \mathrm{Ni}$ & 78 & 22 & 67 & 33 & 49 & 35 & 16 \\
\hline $\mathrm{Cu}_{2} \mathrm{Ni}_{2}$ & 50 & 50 & 89 & 11 & 48 & 39 & 13 \\
\hline $\mathrm{CuNi}_{3}{ }^{2}$ & 26 & 74 & 1.00 & 0 & 45 & 38 & 17 \\
\hline $\mathrm{Ni}_{4}{ }^{\mathrm{d}}$ & 4 & 96 & - & -- & - & - & $\ldots$ \\
\hline
\end{tabular}

a The following IMFPs (in $\AA$ ) were used in converting $2 \mathrm{p}_{32}$ intensities into relative concentrations: $\mathrm{Cu}^{0}(10.9) ; \mathrm{Cu}_{2} \mathrm{O}(12.0) \mathrm{Ni}^{0}(12.0)$; $\mathrm{NiO}(13.5) ; \mathrm{Ni}(\mathrm{OH})_{2}(13.9)$.

Total content regardless of oxidation state.

${ }^{c}$ Based on $\mathrm{Cu}\left(\mathrm{L}_{3} \mathrm{M}_{4,5} \mathrm{M}_{4,5}\right)$ Auger spectrum.

¿ XPS data could not be quantified accurately due to incomplete removal of the surface layer.
Table IV. Alloy composition of electrodeposited films.

\begin{tabular}{|c|c|c|c|}
\hline \multirow[b]{2}{*}{ Complex } & \multirow{2}{*}{$\frac{\mathrm{XRD}}{\mathrm{Cu}-\mathrm{Ni} \text { alloy }}$} & \multicolumn{2}{|c|}{ XPS } \\
\hline & & $\begin{array}{l}\text { Cu-Ni alloy } \\
\text { Method I }\end{array}$ & $\begin{array}{l}\text { Cu-Ni alloy } \\
\text { Method II }\end{array}$ \\
\hline $\begin{array}{l}\mathrm{Cu}_{4} \\
\mathrm{Cu}_{3} \mathrm{Ni} \\
\mathrm{Cu}_{2} \mathrm{Ni}_{2} \\
\mathrm{CuNi}_{3} \\
\mathrm{Ni}_{4}\end{array}$ & $\begin{array}{l}\mathrm{Cu}_{88} \mathrm{Ni}_{12} \\
\mathrm{Cu}_{78} \mathrm{Ni}_{24} \\
\mathrm{Cu}_{54} \mathrm{Ni}_{45} \\
\mathrm{Cu}_{38} \mathrm{Ni}_{62}\end{array}$ & $\begin{array}{c}-- \\
\mathrm{Cu}_{84} \mathrm{Ni}_{16} \\
\mathrm{Cu}_{66} \mathrm{Ni}_{34} \\
\mathrm{Cu}_{52} \mathrm{Ni}_{48}\end{array}$ & $\begin{array}{l}-\overline{C u} \\
\mathrm{Cu}_{80} \mathrm{Ni}_{20} \\
\mathrm{Cu}_{65} \mathrm{Ni}_{35} \\
\mathrm{Cu}_{43} \mathrm{Ni}_{57}\end{array}$ \\
\hline
\end{tabular}

aPS data are the results of analysis of a single deposition from each, of the complexes and the XRD data are an average of two depositions from each complex.

Determined from the (111) reflection.

Calculated using $\mathrm{Cu}^{0} / \mathrm{Ni}^{0}$ ratio of integrated peak intensities from $2 p_{3 / 2}$ spectra and metallurgical alloy sensitivity factor.

Calculated using $\mathrm{Cu}^{0}$ and $\mathrm{Ni}^{0}$ percentages from mass balance data in Table III and complex stoichiometry.

XPS data could not be quantified accurately due to incomplete removal of the surface oxide film after 2 min of sputtering.

$\left(\mu_{4}-\mathrm{O}\right)(\text { denc) })_{4} \mathrm{Ni}_{4}\left(\mathrm{H}_{2} \mathrm{O}\right)_{4} \mathrm{Cl}_{6}$, it is not capable of separating compounds whose molecular weights are nearly the same. The presence of copper in the $\mathrm{Ni}_{4}$ deposit was subsequently confirmed by the XPS analysis.

Figure 4 summarizes the results of the XRD analysis for $\mathrm{Cu}-\mathrm{Ni}$ alloy composition and the EDS analysis for total copper and nickel content of the films. In most cases only the (111) and (200) diffraction peaks were of sufficient intensity to be useful in determining alloy lattice parameters. For the electrodeposition from $\left(\mu_{4}-\mathrm{O}\right)(\mathrm{denc})_{4} \mathrm{Cu}_{4} \mathrm{Cl}_{6}$, the lattice parameter of the film agreed with that expected for pure copper metal. The XRD and EDS analyses were similar for both the as-deposited and alumina-polished films. A maximum concentration of nickel in the alloy $(62 \%)$ was obtained for the $\left(\mu_{4}-\mathrm{O}\right)(\text { denc })_{4} \mathrm{Ni}_{4}\left(\mathrm{H}_{2} \mathrm{O}\right) 4 \mathrm{Cl}_{6}$ complex.

Diffraction patterns of the films frequently contained one to three additional sets of diffraction lines arising from three separate cubic lattices in addition to the $\mathrm{Cu}-\mathrm{Ni}$ alloy pattern. The relative intensities of each set of diffraction lines differed for each deposit. A least squares analysis of the average $2 \theta$ positions for the three patterns gave lattice parameters of $a=4.096,4.263$, and $4.341 \AA$, respectively. Although various assignments for these patterns is possible, we were able to make a reasonable assignment only for the set belonging to $\mathrm{Cu}_{2} \mathrm{O}(a=4.271){ }^{47}$

We used XPS analysis of the electrodeposits to assign oxidation states and chemical environments of the copper and nickel compounds formed during deposition. Preliminary XPS analysis of the as-deposited $\mathrm{Cu}_{3} \mathrm{Ni}$ film showed the presence of carbon, oxygen, copper, and nickel. The nickel was present mostly as $\mathrm{Ni}(\mathrm{OH})_{2}$, with some $\mathrm{NiO}$, and the copper was present as a mixture of $\mathrm{Cu}_{2} \mathrm{O}$ and $\mathrm{Cu}(\mathrm{OH})_{2}$.

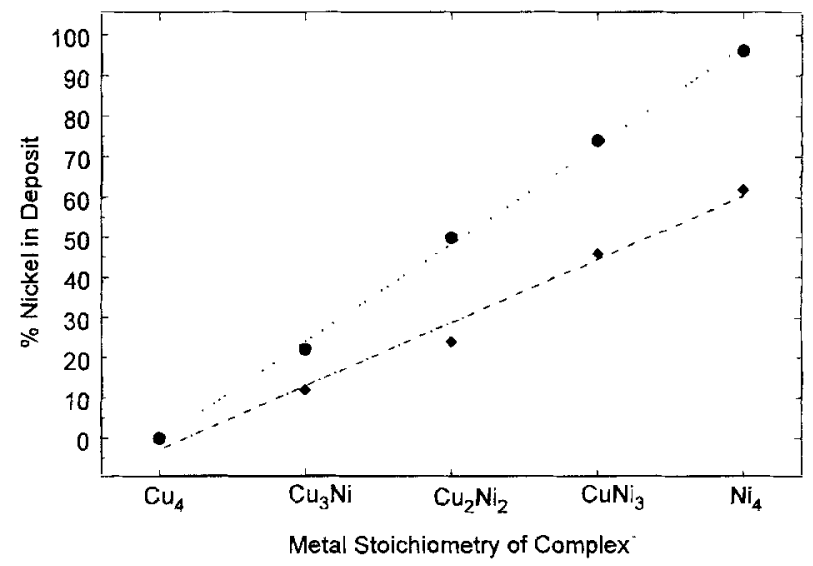

Fig. 4. The percentage of nickel in the Cu-Ni alloy as determined by XRD (- - - - ) and the percentage of total nickel in the deposited film as determined by $\operatorname{EDS}(\ldots \ldots)$. both as a function of the precursor complex metal stoichiometry. 

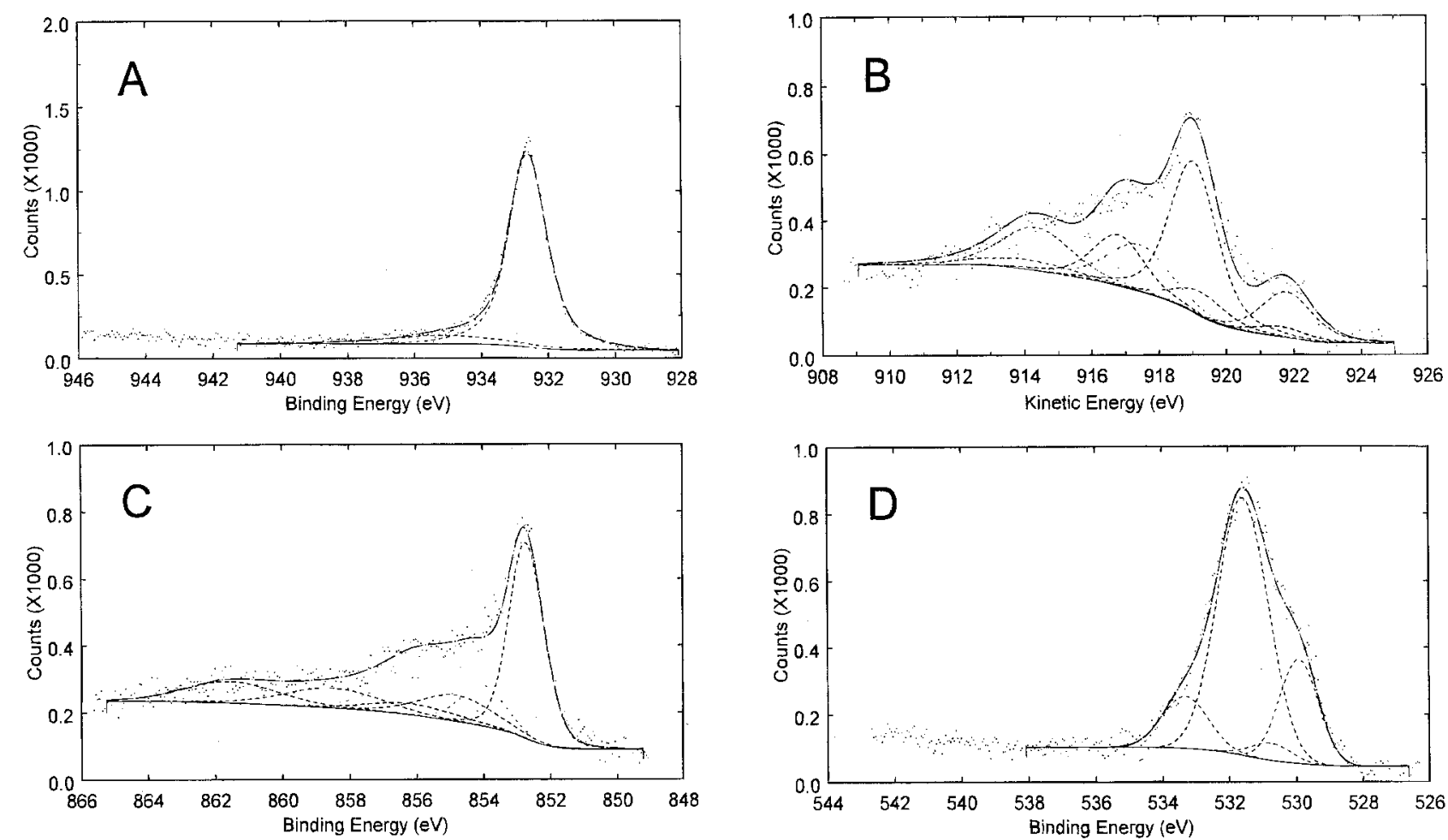

Fig. 5. The (A) $\mathrm{Cu}_{2} \mathrm{p}_{3 / 2}$, (B) $\mathrm{Cu}\left(\mathrm{L}_{3} \mathrm{M}_{4,5} \mathrm{M}_{4,5}\right)$ x-ray induced Auger, (C) Ni2 $\mathrm{p}_{3 / 2}$ and (D) O1s, XPS spectra of polished $\mathrm{Cu}_{2} \mathrm{Ni}_{2}$ deposition affer $1 \mathrm{~min}$ of $\mathrm{Ar}^{+}$sputtering.

The XPS of a polished film showed similar nickel species on the surface, while the copper surface species was essentially $\mathrm{Cu}_{2} \mathrm{O}$.

XPS studies of metals exposed to room temperature air reveal a thin natural passivation layer of oxidative products that protects the metal from further corrosion. ${ }^{48,49}$ For nickel, the parent element can be readily distinguished from corrosion compounds using the chemical shift of $\mathrm{Ni}_{2} \mathrm{p}_{3 / 2}$ and $\mathrm{O} 1 \mathrm{~s}$, satellite production, and multiplet splitting. As described previously, the chemical shift of the $x-$ ray induced $\mathrm{Cu}\left(\mathrm{L}_{3} \mathrm{M}_{4,5} \mathrm{M}_{4,5}\right)$ Auger signal was used to differentiate $\mathrm{Cu}_{2} \mathrm{O}$ and $\mathrm{Cu}^{0}$. $\mathrm{CuO}$ and $\mathrm{Cu}(\mathrm{OH})_{2}$ are readily distinguishable from $\mathrm{Cu}^{0}$, with 1.3 and $1.9 \mathrm{eV}$ chemical shifts, respectively. The identification of oxides and hydroxides of a $\mathrm{Cu}-\mathrm{Ni}$ alloy is complicated since the chemical shift of the O1s signals of several species of copper and nickel are similar (Table I) and thus cannot be used to identify element-specific compounds.

The $\mathrm{Cu} 2 \mathrm{p}_{3 / 2}, \mathrm{Cu}\left(\mathrm{L}_{3} \mathrm{M}_{4,5} \mathrm{M}_{4,5}\right), \mathrm{Ni} 2 \mathrm{p}_{3 / 2}$, and $\mathrm{O} 1 \mathrm{~s}$ spectra for a polished $\mathrm{Cu}_{2} \mathrm{Ni}_{2}$ deposit following $1 \mathrm{~min}$ of $3 \mathrm{keV} \mathrm{Ar}{ }^{+}$sputtering are shown in Fig. 5A-D, respectively. Depth profiling of as-polished $\mathrm{Cu}_{2} \mathrm{Ni}_{2}$ using argon sputtering showed that the copper species in the passive surface layer were sputtered in less than $30 \mathrm{~s}$ and removal of nickel passivation species was achieved in less than $45 \mathrm{~s}$. The Auger spectrum (Fig. $5 \mathrm{~B}$ ), which was unchanged during profiling below the surface layer, indicated that the bulk film contained $\mathrm{Cu}_{2} \mathrm{O}$ in addition to $\mathrm{Cu}^{0}$. This result is consistent with identification of $\mathrm{Cu}_{2} \mathrm{O}$ in the XRD analysis.

Depth profiling over a $6 \mathrm{~min}$ period of sputtering revealed a gradually changing intensity in the nickel spectra marked by the appearance of $\mathrm{Ni}^{0}$ after about $\sim 5 \mathrm{~s}$. The $\mathrm{Ni}^{0}$ signal was the dominant peak in the $N i 2 p_{3 / 2}$ spectrum after an additional $30 \mathrm{~s}$ of sputtering, which included peaks corresponding to $\mathrm{NiO}$ and $\mathrm{Ni}(\mathrm{OH})_{2}$. The $\mathrm{Ni} 2 \mathrm{p}_{3 / 2}$ spectrum changed more gradually thereafter, most noticeably in terms of an increasing $\mathrm{Ni}^{0}$ peak, and this contributed to a decreasing $\mathrm{Cu}^{0} / \mathrm{Ni}^{0}$ ratio through the depth profile. The $\mathrm{Ni}_{2 / 2}$ spectrum (Fig. 5C) confirmed the conclusion drawn from the EDS and XRD analyses that the bulk film contained nickel compounds in addition to nickel alloy for mass balance of nickel in the film.
Identification of species in the copper and nickel spectra was guided by the chemical shifts in the 01 s spectrum (Fig. 5D). Chemical shifts of all the spectra indicate $\mathrm{Cu}_{2} \mathrm{O}$, $\mathrm{NiO}, \mathrm{Ni}(\mathrm{OH})_{2}$, and $\mathrm{H}_{2} \mathrm{O}$ in the bulk film. The water is most likely from the alumina polishing step. The assignment of an $\mathrm{O} 1 \mathrm{~s}$ binding energy of about $533 \mathrm{eV}$ to adsorbed water is based on literature values (Table I) as well as comparison with O1s spectra of samples from which water was deliberately excluded.

XPS analysis of the other electrodeposits confirmed that while $\mathrm{Cu}(\mathrm{OH})_{2}$ and $\mathrm{Cu}_{2} \mathrm{O}$ were components of the native passivation layer of as-deposited films, the bulk contained only $\mathrm{Cu}^{0}$ and $\mathrm{Cu}_{2} \mathrm{O}$. However, $\mathrm{NiO}$ and $\mathrm{Ni}(\mathrm{OH})_{3}$ were found both on the surface and in the bulk of all the mixed-metal electrodeposits.

Although the surface passivation layer was readily removed with argon sputtering, this procedure is complicated by several undesirable phenomena. Argon sputtering of $\mathrm{Cu}-\mathrm{Ni}$ alloys is known to cause preferential etching of copper in the alloy, leading to nickel enrichment in the $\mathrm{Ar}^{+}$-altered surface layer. ${ }^{50}$ In addition, $\mathrm{Cu}$ and $\mathrm{Ni}$ oxides undergo preferential sputtering of the oxygen such that $\mathrm{NiO}$ is reduced to $\mathrm{Ni}^{0}$ and/or $\mathrm{CuO}$ is reduced to $\mathrm{Cu}_{2} \mathrm{O}$, with the concomitant loss of $\mathrm{O}_{2},{ }^{51,52}$ Although reduction of $\mathrm{Cu}_{2} \mathrm{O}$ has been reported, ${ }^{52}$ its rate of reduction was shown to be negligible compared with that of $\mathrm{CuO} .{ }^{51} \mathrm{Ni}(\mathrm{OH})_{2}$ shows no indication of reduction to $\mathrm{Ni}^{0}$ on $\mathrm{Ar}^{+}$sputtering. ${ }^{52,53}$

For the above reasons we investigated preferential sputtering of the metallurgical copper-nickel alloy and sputter reduction of $\mathrm{NiO}$ and $\mathrm{Cu}_{2} \mathrm{O}$. The thin passivation layer formed on the polished elemental and alloy standards was removed by $30-45 \mathrm{~s}$ of $\mathrm{Ar}^{+}$sputtering at $3 \mathrm{kV}$, with $\mathrm{Cu} 2 \mathrm{p}_{3 / 2}$ and $\mathrm{Ni} 2 \mathrm{p}_{3 / 2}$ binding energies within $0.1 \mathrm{eV}$ of reference values and a $\mathrm{Cu}\left(\mathrm{L}_{3} \mathrm{M}_{4,5} \mathrm{M}_{4.5}\right)$ spectrum characteristic of $\mathrm{Cu}^{0}$ (Table II). We estimate the thickness of the natural passivation layer of the metallurgical $\mathrm{Cu}-\mathrm{Ni}$ alloy to be $30-45 \AA$. Depth profiling of the $\mathrm{Cu}-\mathrm{Ni}$ metallurgical alloy following removal of the passivation layer showed no preferential sputtering of copper for sputter times up to $5 \mathrm{~min}$, the longest time employed here. We thus conclude that preferential sputtering of copper in the alloy component is inconsequential. 
Reduction of $\mathrm{NiO}$ and $\mathrm{Cu}_{2} \mathrm{O}$ was studied using $\mathrm{Ar}^{+}$accelerating voltages of $1-3 \mathrm{kV}$ and sputtering times of the order of $5 \mathrm{~min}$. Reduction of $\mathrm{NiO}$ to $\mathrm{Ni}^{0}$ occurred under all sputtering conditions, as evidenced by the appearance of an $\mathrm{Ni}_{2} \mathrm{p}_{3 / 2}$ peak at $852.5 \mathrm{eV}$. A typical reduction rate of $\mathrm{NiO}$ to $\mathrm{Ni}^{\circ}$ was of the order of $7 \%$ per minute (uncorrected intensities) over the course of $3 \mathrm{~min}$ for sputtering at $3 \mathrm{kV}$. However, since no reduction of $\mathrm{Cu}_{2} \mathrm{O}$ was observed using similar sputtering times and conditions, reduction of $\mathrm{NiO}$, but not $\mathrm{Cu}_{2} \mathrm{O}$, is likely on sputter etching of our electrodeposits.

$X P S$ quantitation of electrodeposited species. - Based on the above results, a comprehensive XPS analysis of electrodeposited films began with qualitative characterization of the native oxide layer of freshly polished films using chemical shifts of $\mathrm{Cu} 2 \mathrm{p}_{3 / 2}, \mathrm{Ni2} \mathrm{p}_{3 / 2}, \mathrm{O} 1 \mathrm{~s}$, and $\mathrm{Cu}\left(\mathrm{L}_{3} \mathrm{M}_{4.5} \mathrm{M}_{4.5}\right)$ lines. This was followed by argon sputtering for $30 \mathrm{~s}$ intervals, with XPS analysis following each sputtering session, for a total sputtering time of $2 \mathrm{~min}$. Quantitative analysis of the bulk film was done on spectra acquired after 1 min of sputtering. This choice of sputtering time for the electrodeposits was based on the depth profiles of the electrodeposits and the $\mathrm{Cu}-\mathrm{Ni}$ metallurgical alloy. $\mathrm{Ar}^{+}$sputtering at $3 \mathrm{kV}(1 \mathrm{~min})$ is sufficient to remove the surface layer but minimizes the amount of bulk film NiO reduction.

A semiquantitative calculation of copper and nickel mass balance of the films was performed using the $2 \mathrm{p}_{3 / 2}$ spectrum of nickel and the $2 \mathrm{p}_{3 / 2}$ and $\mathrm{Cu}\left(\mathrm{L}_{3} \mathrm{M}_{4,5} \mathrm{M}_{4.5}\right)$ spectra of copper. We used the inelastic mean-free path (IMFP) of the photogenerated electrons as a measure of surface sensitivity for the components of the deposited films. ${ }^{54}$ Attenuation length (AL) and the electron escape depth (ED) are two other expressions frequently used as measures of surface sensitivity for electron-based probes of surface properties. ${ }^{54}$ The calculated IMFPs ${ }^{55}$ used are given in Table III. However, there is large uncertainty in determining surface sensitivity of XPS. Recent reviews of quantitative analysis using electron spectroscopies highlight the challenge of determining meaningful measures of surface sensitivity. ${ }^{56,57}$

Relative $\mathrm{Cu}^{0}$ and $\mathrm{Cu}_{2} \mathrm{O}$ components of the $\mathrm{Cu} 2 \mathrm{p}_{3 / 2}$ spectra were determined from the $\mathrm{Cu}\left(\mathrm{L}_{3} \mathrm{M}_{4,5} \mathrm{M}_{4,5}\right)$ deconvoluted spectrum of the bulk film with correction for differences in the IMFP of electrons in $\mathrm{Cu}^{0}$ and $\mathrm{Cu}_{2} \mathrm{O}$. The partitioning of total deposited copper into $\mathrm{Cu}^{\mathrm{B}}$ and $\mathrm{Cu}_{2} \mathrm{O}$ is given in Table III.

Energy, FWHM, and area constraints of the multiplet splitting and shake-up peaks for $\mathrm{Ni}^{0}, \mathrm{NiO}$, and $\mathrm{Ni}(\mathrm{OH})_{2}$ were used to facilitate deconvolution of the $\mathrm{Ni}_{2 / 2} \mathrm{p}_{3 / 2}$ spectra. Although $\mathrm{Ni}^{0}, \mathrm{NiO}$, and $\mathrm{Ni}(\mathrm{OH})_{2}$ assignments were made for the nickel spectrum, deconvolution of a spectrum as complex as that of $\mathrm{Ni}_{2} \mathrm{p}_{3 / 2}$ in Fig. $5 \mathrm{C}$ is regarded as semiquantitative. We were unable to fit the Ni2 $\mathrm{p}_{3 / 2}$ spectra of the films without including $\mathrm{Ni}(\mathrm{OH})_{2}$. The peak at $852.5 \mathrm{eV}$ and associated shake-up peaks in the $\mathrm{Ni} 2 \mathrm{p}_{3 / 2}$ spectrum were used to determine the $\mathrm{Ni}^{0}$ content of the alloy. The other peaks in the $854-864 \mathrm{eV}$ region arise from overlap of $\mathrm{NiO}$ and $\mathrm{Ni}(\mathrm{OH})_{2}$. While we have employed deconvolution techniques for this region to identify nickel compounds found in the deposits, resolving this structure is accomplished with a larger error than that associated with quantitation of the $\mathrm{Ni}^{0}$. Therefore, there is less certainty associated with the estimates of $\mathrm{NiO}$ and $\mathrm{Ni}(\mathrm{OH})_{2}$ contents given in Table III.

It was anticipated that the relatively simple O1s spectra could help quantitate the nickel species as an alternative to deconvoluting the more complex $\mathrm{Ni}_{2} \mathrm{p}_{3 / 2}$ spectra. However, we found that although sputtering of the surface layer is effective in removing copper and nickel surface passivation species, there was a significant qualitative and quantitative discrepancy between the $\mathrm{Cu}$ and $\mathrm{Ni} 2 \mathrm{p}_{3 / 2}$ and $\mathrm{O} 1 \mathrm{~s} \mathrm{spec}-$ tra. This discrepancy was readily apparent from analysis of the $\mathrm{Cu}_{4}$ sample. The $\mathrm{Cu} 2 \mathrm{p}_{3 / 2}$ spectrum showed only a single peak at $932.4 \mathrm{eV}$ after $30 \mathrm{~s}$ of sputtering, indicating that all the copper was either $\mathrm{Cu}(\mathrm{I})$ or $\mathrm{Cu}^{0}$. The Auger spectrum of the sputtered sample was readily deconvoluted as $\mathrm{Cu}(\mathrm{I})$ and $\mathrm{Cu}^{0}$, with roughly equal intensity for each (Table III). However, measurements showed that the O1s spectrum con- sisted of $21 \% \mathrm{Cu}(\mathrm{OH})_{2}, 72 \% \mathrm{Cu}_{2} \mathrm{O}$, and $7 \% \mathrm{H}_{2} \mathrm{O}$, and that even after $2 \mathrm{~min}$ of sputtering the $\mathrm{Cu}(\mathrm{OH})_{2}$ level was still about $20 \%$ of the total oxygen signal. Since there was no $\mathrm{Cu}$ (II) in the $\mathrm{Cu} 2 \mathrm{p}_{3 / 2}$ spectrum, this O1s signal most likely is due to chemisorbed hydroxyl oxygen from the surface layer that is adsorbed onto the sputtered surface. ${ }^{53}$ We made a similar observation for films containing nickel when comparing hydroxyl intensity in the O1s spectrum with $\mathrm{Ni}(\mathrm{OH})_{2}$ intensity in the $\mathrm{Ni} 2 \mathrm{p}_{3 / 2}$ spectra. Chemisorption of hydroxyl species exaggerated the $\mathrm{Ni}(\mathrm{OH})_{2}$ intensity, invalidating intensity comparisons using the O1s spectra.

Mass balance of nickel, partitioned as $\mathrm{Ni}^{0}, \mathrm{NiO}$, and $\mathrm{Ni}(\mathrm{OH})_{2}$, was determined from the deconvoluted intensities of the $\mathrm{Ni} 2 \mathrm{p}_{3 / 2}$ spectra and was corrected for differences in electron IMF'Ps as described above. The partitioning of total nickel is given in Table III.

Alloy compositions, shown in Table IV, were calculated from the XPS data in two different ways. Method I used the $\mathrm{Cu}^{0} / \mathrm{Ni}^{0}$ ratio of integrated area intensities from the $2 \mathrm{p}_{3 / 2}$ spectra and the $\mathrm{Cu} / \mathrm{Ni}$ metallurgical alloy sensitivity factor. As previously noted, the EDS results indicate that $\left(\mu_{4}-\mathrm{O}\right)(\text { denc })_{4} \mathrm{Cu}_{4-x} \mathrm{Ni}_{x}\left(\mathrm{H}_{2} \mathrm{O}\right)_{x} \mathrm{Cl}_{6}$ stoichiometries are preserved in the films. Hence, it should be possible to calculate alloy compositions from the XPS mass balance data in Table III and the complex stoichiometries, if partitioning of copper and nickel species has been correctly assigned. This is the basis of method II calculation of alloy compositions in Table IV.

\section{Discussion}

Quasi-reversible cyclic voltammograms for the copper containing complexes of $\left(\mu_{4}-\mathrm{O}\right)\left(\right.$ denc) ${ }_{4} \mathrm{Cu}_{4-x} \mathrm{Ni}_{x}\left(\mathrm{H}_{2} \mathrm{O}\right)_{x} \mathrm{Cl}_{6}$ display a reduction peak in the potential region -0.23 to $-0.28 \mathrm{~V} v s . \mathrm{Ag} / \mathrm{AgPF}_{6} / \mathrm{CH}_{3} \mathrm{CN}$ which is associated with a one-electron reduction of $\mathrm{Cu}(\mathrm{II})$ to $\mathrm{Cu}(\mathrm{I})$ for each copper. ${ }^{37}$ Spectroscopic and nuclear magnetic resonance (NMR) data suggest that the DMSO solvent is coordinated to the complexes by DMSO ligand addition to the copper centers, increasing the copper coordination number to six. ${ }^{37}$ Solvation of polynuclear metal complexes by DMSO is well known. ${ }^{59}$ Reduction of $\mathrm{Cu}(\mathrm{I})$ to $\mathrm{Cu}^{0}$ is seen at voltages of $\sim-1.8 \mathrm{~V}$ but the absence of a cyclic voltammetric peak due to decomposition of the complex at this potential precludes assignment of a reduction potential. Although no Ni(II) reduction peak is observed, it appears that the $\mathrm{Ni}$ (II) centers only undergo reduction at potentials of -1.8 to $-2.0 \mathrm{~V} .^{37}$

The cyclic voltammetry of these complexes ${ }^{37}$ has shown that during a linear scan, reduction of these complexes proceeds by an initial one-electron reduction of the $\mathrm{Cu}$ (II) centers to $\mathrm{Cu}(\mathrm{I})$ at significantly more positive potentials than required for reduction of the $\mathrm{Ni}(\mathrm{II})$ centers or decomposition of the complexes. This means that despite the presence of $\mathrm{Cu}(\mathrm{II})$ and $\mathrm{Ni}(\mathrm{II})$ in similar coordination environments within the same molecule, they appear to behave as isolated metal centers. This is also supported by spectroscopic analysis $^{37}$ and magnetic susceptibility data ${ }^{60}$ which indicate that the metal centers in these complexes do not exhibit room temperature electron exchange despite the presence of bridging chloro- and oxo- ligands. However, the reduced complex with the $\mathrm{Cu}(\mathrm{I})$ centers is stable and the simultaneous reduction and deposition of both the $\mathrm{Cu}(\mathrm{I})$ and $\mathrm{Ni}(\mathrm{II})$ does not occur unless a potential of $\sim-2.0 \mathrm{~V}$ is applied. ${ }^{37}$ As is shown below, at this point we get stoichiometric depositon of a single-phase alloy. This most likely occurs because the atomic geometry (proximity) of the core metal atoms thermodynamically favors the formation of an alloy over that of separate deposition (as is found in a mixture of metals).

The $\mathrm{Ni}(\mathrm{II})$ and $\mathrm{Cu}(\mathrm{I})$ centers apparently undergo twoelectron and one-electron reductions, respectively, at potentials that probably differ by less than $200 \mathrm{mV}$ and which cause decomposition of the complexes and subsequent deposition on the electrode surface. It is likely that water, either free or coordinated to nickel, undergoes reduction at potentials less negative than $-2.0 \mathrm{~V}$. 
Electrodeposition in a deaerated solution at approximately $-2.0 \mathrm{~V}$ can include the following reduction reactions at the electrode surface

$$
\begin{gathered}
\mathrm{Cu}(\mathrm{II})+2 e^{-} \rightarrow \mathrm{Cu}^{0} \\
\mathrm{Cu}(\mathrm{II})+e^{-} \rightarrow \mathrm{Cu}(\mathrm{I}) \\
\mathrm{Cu}(\mathrm{I})+e^{-} \rightarrow \mathrm{Cu}^{0} \\
\mathrm{Ni}(\mathrm{II})+2 e^{-} \rightarrow \mathrm{Ni}^{0} \\
\mathrm{Ni}(\mathrm{II})+e^{-} \rightarrow \mathrm{Ni}(\mathrm{I}) \\
\mathrm{Ni}(\mathrm{I})+e^{-} \rightarrow \mathrm{Ni}^{0} \\
2 \mathrm{H}_{2} \mathrm{O}+2 e^{-} \rightarrow \mathrm{H}_{2}+2 \mathrm{OH}^{-}
\end{gathered}
$$

Additional chemical reactions which can occur at the electrode surface during or after the reduction reaction include

$$
\begin{gathered}
\mathrm{Ni}(\mathrm{II})---\mathrm{O} \rightarrow \mathrm{NiO} \\
\mathrm{Cu}(\mathrm{I})---\mathrm{O}--\mathrm{Cu}(\mathrm{I}) \rightarrow \mathrm{Cu}_{2} \mathrm{O} \\
\mathrm{Cu}(\mathrm{II})+2 \mathrm{OH}^{-} \rightarrow \mathrm{Cu}(\mathrm{OH}) \\
\mathrm{Ni}(\mathrm{II})+2 \mathrm{OH}^{-} \rightarrow \mathrm{Ni}(\mathrm{OH}) \\
\mathrm{Cu}(\mathrm{I})----\mathrm{Cl} \rightarrow \mathrm{CuCl} \\
\mathrm{Cl}-\mathrm{Cu}(\mathrm{II})--\mathrm{Cl} \rightarrow \mathrm{CuCl}_{2} \\
\mathrm{Cl}--\mathrm{Ni}(\mathrm{II})---\mathrm{Cl} \rightarrow \mathrm{NiCl}_{2}
\end{gathered}
$$

The nature of the actual species undergoing reduction or compound formation in Eq. 2-15 is not clear. The notation of Eq. 9-15 is intended to convey coordination of oxo- and chloro- ligands from the precursor complexes with metal ions prior to compound formation.

Of the above reaction schemes, several are either unobserved, unexpected, or both. Chlorine was never detected by XPS or EDS. Chloride ions are probably complexed by the supporting electrolyte and remain in solution. The formation of $\mathrm{Cu}^{\circ}$ through an intermediate $\mathrm{Cu}(\mathrm{I})$ species within the complex is supported by the observations that (i) a stable and reversible $\mathrm{Cu}(\mathrm{I})_{3} \mathrm{Cu}$ (II) complex is formed at potentials much less negative than those required for $\mathrm{Cu}^{0}$ deposition, ${ }^{37}$ (ii) that $\mathrm{Cu}_{2} \mathrm{O}$ is a significant component of the $\mathrm{Cu}_{4}$ bulk film (Table III), and (iii) that no $\mathrm{Cu}(\mathrm{II})$ oxide species were detected in the bulk film. In addition, the reduction of $\mathrm{Cu}(\mathrm{II})$ during the electrodeposition has been shown to occur in two consecutive charge transfers (Eq. 3 and 4). ${ }^{61}$ The existence of an $\mathrm{Ni}(\mathrm{I})$ intermediate in other $\mathrm{Ni}$ (II) reductions has been proposed..$^{3}$ Although $\mathrm{Ni}(\mathrm{I})$ compounds were not found in the film, $\mathrm{Ni}$ (II) reduction via formation of an $\mathrm{Ni}(\mathrm{I})$ intermediate cannot be ruled out.

The likely reductions and compound formations at a constant -2.0 V reduction potential are expected to be competitive during electrodeposition of a given heterotetranuclear complex. The alloy compositions obtained with different complex stoichiometries and the alloy/compound distribution of the films provide some insight into the mechanism of film deposition from these complexes. A most striking result is the relationship between copper content of the alloy and copper content of the complex illustrated in Fig. 6. These data indicate that copper still appears more noble despite coordination of both $\mathrm{Cu}$ and $\mathrm{Ni}$ within the same molecule. Copper is always found at higher concentrations in the alloy compared to the $\mathrm{Cu} / \mathrm{Ni}$ ratio in the complex from which it is made. However, in contrast to classical electrodeposition, the EDS data (Table III) shows that the net mass balance for the $\mathrm{Cu}$ and $\mathrm{Ni}$ in the deposited film correlates well with the precursor complex stoichiometry.

Table IV shows that alloy composition from XRD measurements is in good agreement with compositions determined by the two XPS-based methods. The XRD values have an average error of $\sim 3 \%$ for the $\mathrm{Cu}_{88} \mathrm{Ni}_{12}$ alloy and this error increases to $\sim 8 \%$ for $\mathrm{Cu}_{38} \mathrm{Ni}_{62}$. These errors depend primarily on errors in assigning locations of the (111) and

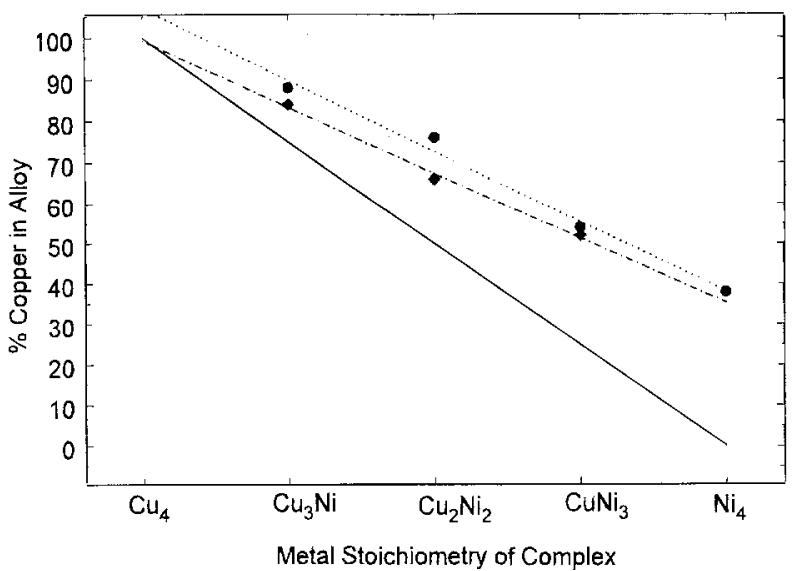

Fig. 6. Percentage of $\mathrm{Cu}$ in the alloy as given by XRD (..... and XPS method I (- - - ) as a function of precursor complex meial stoichiometry. The solid line indicates values expected for coppernickel alloys as the sole deposition product.

(200) peaks. These peaks increase in width as the nickel concentration increases, giving rise to a larger error at higher nickel concentrations. The XPS values have a composition independent error of $\sim 10 \%$ for compositions based on referencing the metallurgical alloy (method I). The mass balance calculation of the compositions (method II) has a larger error due to accumulated uncertainties arising from spectra deconvolution and the IMFPs.

The mass balance data in Table $\mathrm{II}$ can be used to compare copper and nickel oxide formation on electrodeposition. Mass balance of oxides, assuming quantitative conversion of the $\mu_{4}$-O in the complexes into oxide, predicts the following relation for moles of oxide per mole of complex

$$
\text { oxide }=f_{\mathrm{Cu}_{2} \mathrm{O}}(4-x) / 2+f_{\mathrm{NiO} O} x
$$

where oxide is the moles of oxide per mole of complex, $x$ is the nuclearity of the nickel in $\left(\mu_{4}-\mathrm{O}\right)(\text { denc })_{4} \mathrm{Cu}_{4-x} \mathrm{Ni}_{x}$ $\left(\mathrm{H}_{2} \mathrm{O}\right)_{x} \mathrm{Cl}_{6}$, and $f_{\mathrm{C}_{22} \mathrm{O}}$ and $f_{\mathrm{NiO}}$ are the atom fractions of $\mathrm{Cu}_{2} \mathrm{O}$ and $\mathrm{NiO}$, respectively. Mass balance of the oxo- ligand places an upper bound of one mole of oxide per mole of complex, and loss of oxide by reduction of $\mathrm{NiO}$ during $\mathrm{Ar}^{+}$ sputtering ${ }^{52,53}$ determines the lower limit of moles of oxide in Eq. 16.

The oxide data for the depositions from the $\mathrm{Cu}_{4-x} \mathrm{Ni}_{x}$ complexes (Fig. 7) shows a smooth increase of nickel oxide with increasing nickel in the complex, a corresponding decrease in copper oxide, and an approximate mass balance of the $\mu_{4}$-oxygen with respect to oxide formation. However, errors are of the order of $15-20 \%$ at the present level of quantification. The general trend is consistent with copper

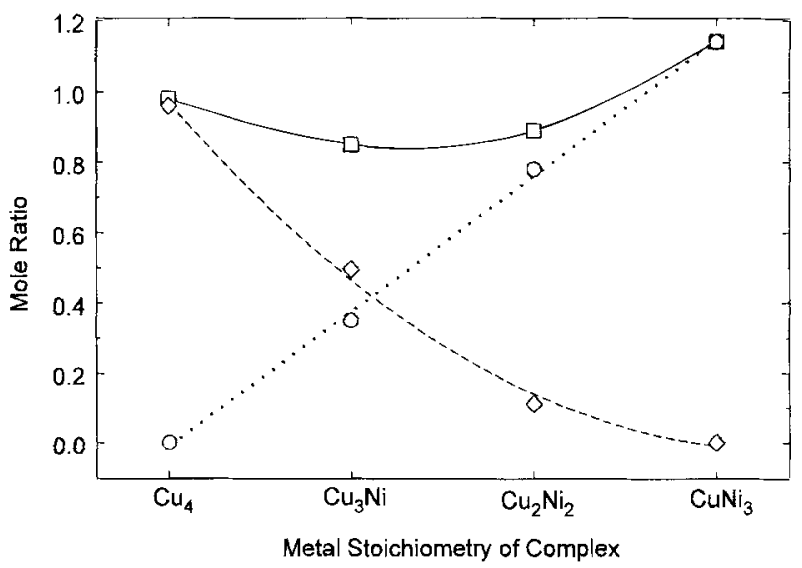

Fig. 7. Mass balance of the central $\mu_{4}$-oxygen using Eq. 16 $(-\square-)$, and the mole fractions of the copper oxide $(-\diamond-)$ and nickel oxide $(\ldots \circ \cdots)$, all as a function of the complex metal stoichiometry. 


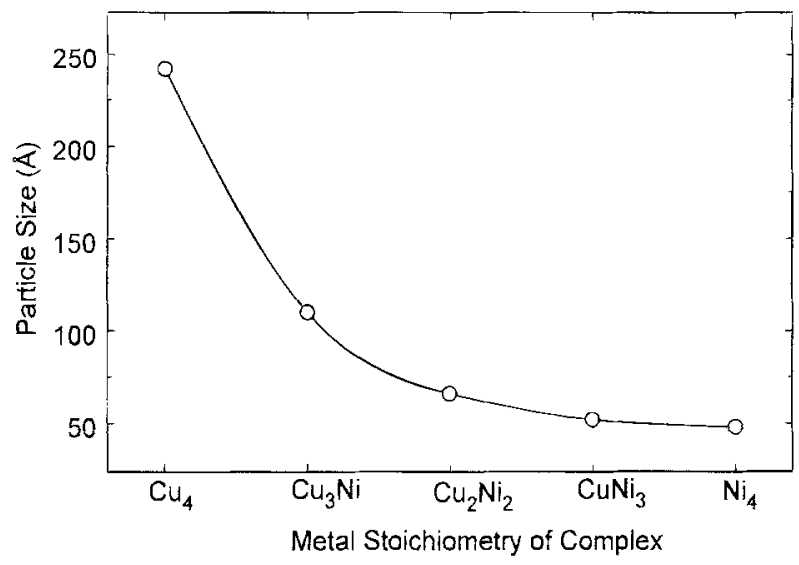

Fig. 8. The effect of complex metal stoichiometry on the alloy particle size (crystallinity) as calculated by the Scherrer equation.

and nickel oxide formation arising from metal ion coordination to the oxo-ligand, and not from an oxygen-containing impurity. Further refinement of the quantitative analysis of copper and nickel oxides should include experimentally determined IMFPs, as well as comparison of known mixtures of copper and nickel oxide standards.

Attempts at using XPS to quantify the alloy and nickel compound in the deposition made from $\left(\mu_{4}-\mathrm{O}\right)(\text { denc })_{4}$ $\mathrm{Ni}_{4}\left(\mathrm{H}_{2} \mathrm{O}\right)_{4} \mathrm{Cl}_{6}$ were unsuccessful. This film did not withstand polishing and consequently only the as-deposited film was analyzed. The relative intensities in the $N i 2 \mathrm{p}_{3 / 2}$ spectrum following $2 \mathrm{~min}$ of $\mathrm{Ar}^{+}$sputtering were $40 \%$ $\mathrm{Ni}(\mathrm{OH})_{2}, 35 \% \mathrm{NiO}$, and $25 \% \mathrm{Ni}^{0}$, based on uncorrected intensities. The high $\mathrm{Ni}(\mathrm{OH})_{2}$ intensity indicates that much of the native passivation layer was not completely sputtered, leading to attenuation of the bulk signal. The presence of $\mathrm{Cu}(\mathrm{OH})_{2}$ as $\mathrm{Cu}(\mathrm{II})$ in the $\mathrm{Cu} 2 \mathrm{p}_{3 / 2}$ spectrum is consistent with this interpretation since we only observed $\mathrm{Cu}(\mathrm{OH})_{2}$ in the surface passivation layer of other deposits. Several additional minutes of sputtering reduced the hydroxide signal. However, such extensive sputtering of $\mathrm{NiO}$ has been shown by us and others ${ }^{52,53}$ to enhance $\mathrm{Ni}^{0}$ due to reduction of $\mathrm{NiO}$. It is unclear why the passivation layer is so much thicker for the deposition from reduction of the $\left(\mu_{4}-\mathrm{O}\right)$ (denc) ${ }_{4} \mathrm{Ni}_{4}\left(\mathrm{H}_{2} \mathrm{O}\right)_{4} \mathrm{Cl}_{6}$ complex.

Interestingly, $\mathrm{Ni}(\mathrm{OH})_{2}$ is a consistent minor portion of the heteronuclear electrodeposits (Table III). Because ambient moisture was excluded from the electrodeposition system, nickel hydroxide formation is limited by hydroxyl ions generated from reduction of water molecules coordinated to nickel. A larger uncertainty is assigned to quantitation of $\mathrm{Ni}(\mathrm{OH})_{2}$, however, since there are some known nickel hydroxide species, all with different densities and corresponding IMFPs, yet with similar XPS energies. ${ }^{62}$ Despite these possible sources of error in quantifying $\mathrm{Ni}(\mathrm{OH})_{2}$ it seems likely that $\mathrm{Ni}(\mathrm{OH})_{2}$ should be a minor component of the film, as observed

Another result that highlights systematic behavior in alloy deposition from these complexes is the trend in metal/ alloy particle size. A measure of the average particle size of the electrodeposited alloys is illustrated in Fig. 8. The particle size of the $\mathrm{Cu}_{4}$ copper deposit is similar to that reported by others for several $\mathrm{Cu}-\mathrm{Zn}$ and $\mathrm{Cu}-\mathrm{Sn}$ alloys. ${ }^{4}$ However, particle sizes of the $\mathrm{Cu}_{4-x} \mathrm{Ni}_{x}$ alloys indicate that increasing the nickel content of the deposition solution leads to deposition of finer grain alloys. Since particle size is known to affect catalytic, mechanical, and electrical properties of metals and alloys, control of it is of particular importance in alloy electrodeposition. Although little has been said in the literature with regard to particle size of electrodeposited $\mathrm{Cu}-\mathrm{Ni}$ alloys, control of it during nickel deposition has received greater attention. ${ }^{44}$ Understanding the relationship between the rate of crystal growth and the rate of nucleation during deposition of $\left(\mu_{4}-\mathrm{O}\right) \mathrm{L}_{4}$ $\mathrm{Cu}_{4-x} \mathrm{Ni}_{x}\left(\mathrm{H}_{2} \mathrm{O}\right)_{x} \mathrm{Cl}_{6}$ complexes may make it possible to con- trol the particle size of the deposit. Control of growth and nucleation rates is an unexplored aspect of $\left(\boldsymbol{\mu}_{4}-\mathrm{O}\right) \mathrm{L}_{4}$ $\mathrm{Cu}_{4-x} \mathrm{Ni}_{x}\left(\mathrm{H}_{2} \mathrm{O}\right)_{x} \mathrm{Cl}_{6}$ complex deposition.

The electrodeposition of these complexes can be compared with their thermolysis. Thermolytic decomposition in an argon atmosphere and in the absence of an external reductant such as $\mathrm{H}_{2}$ results in the formation of $\mathrm{Cu}-\mathrm{Ni}$ alloys with inclusion of their respective oxides. ${ }^{33}$ Depending on the temperature, thermolysis gives $\mathrm{Cu}^{\%} / \mathrm{CuCl}, \mathrm{Cu}^{0} / \mathrm{CuO} /$ $\mathrm{Cu}_{2} \mathrm{O}$, or $\mathrm{Cu}^{0} / \mathrm{Cu}_{2} \mathrm{O}$ for $T=150,250$, or $350^{\circ} \mathrm{C}$, respectively, for $x=0, \mathrm{C}_{50} \mathrm{Ni}_{50} / \mathrm{NiO}$ at 150,250 , or $350^{\circ} \mathrm{C}$ for $x=2$, and $\mathrm{Ni}^{0} / \mathrm{NiO}$ at 150,250 , or $350^{\circ} \mathrm{C}$ for $x=4$. Oxide concentrations were estimated by XRD to be of the order of $5-30 \%$ for some of the complexes. Thermogravimetric analysis showed that ligand loss was rapid and complete at $46^{\circ} \mathrm{C}$ for the $x=0$ complex, and water and ligand loss was complete in $20 \mathrm{~h}$ at $150^{\circ} \mathrm{C}$ for the $x=4$ complex. On this basis one does not expect the thermolytic decomposition products to be contaminated by reactions with water. It is apparent that despite attempts to exclude ambient oxygen, oxide formation occurs for both electrodeposition and thermolytic decomposition of $\left(\mu_{4}-\mathrm{O}\right)$ (denc) $)_{4} \mathrm{Cu}_{4-x} \mathrm{Ni}_{x}\left(\mathrm{H}_{2} \mathrm{O}\right)_{x} \mathrm{Cl}_{6}$ complexes because of the presence of the $\mu_{4}$-oxygen atom.

\section{Conclusion}

Energy dispersive $\mathrm{x}$-ray analysis of the deposition products shows that heterotetranuclear complexes $\left(\mu_{4}-\mathrm{O}\right)$ (denc) $)_{4} \mathrm{Cu}_{4-x} \mathrm{Ni}_{x}\left(\mathrm{H}_{2} \mathrm{O}\right)_{x} \mathrm{Cl}_{6}$ with $x=1,2$, or 3 , are totally electrodeposited from $0.2 \mathrm{M}$ TBAHFP/DMSO solutions at room temperature at -2.0 to $-2.2 \mathrm{~V} v s . \mathrm{Ag} / 0.01 \mathrm{M} \mathrm{AgPF}_{6} /$ $\mathrm{CH}_{3} \mathrm{CN}$ to give well-adhering compositionally uniform thin films on a $\mathrm{Pt}$ electrode.

XRD and XPS reveal that the bulk films consist of single-phase $\mathrm{Cu}-\mathrm{Ni}$ alloys together with codeposited $\mathrm{Cu}_{2} \mathrm{O}$, $\mathrm{NiO}$, and $\mathrm{Ni}(\mathrm{OH})_{2}$. There is no evidence for deposition of metal chlorides. Alloy characterization by XRD and XPS gives consistent results despite their inherent limitations in this application. The ratio $\mathrm{Cu}_{2} \mathrm{O} / \mathrm{Cu}^{0}$ is close to unity in the deposit made with $x=0$ in $\left(\mu_{4}-\mathrm{O}\right)(\text { denc })_{4} \mathrm{Cu}_{4-x} \mathrm{Ni}_{x}\left(\mathrm{H}_{2} \mathrm{O}\right)_{x} \mathrm{Cl}_{6}$ and decreases to zero with $x=3$. Electrodeposition of these complexes results in reduction of about half their Ni(II) centers to $\mathrm{Ni}^{0}$ in the $\mathrm{Cu}-\mathrm{Ni}$ alloys, with the balance consisting of $37 \pm 2 \% \mathrm{NiO}$ and $15 \pm 2 \% \mathrm{Ni}(\mathrm{OH})_{2}$. As a result, the electrodeposited $\mathrm{Cu}-\mathrm{Ni}$ alloys are richer in $\mathrm{Cu}$ than the complexes from which they are deposited. Even though this implies that $\mathrm{Cu}(\mathrm{II})$ is reduced more easily than $\mathrm{Ni}(\mathrm{II})$, their presence in the same molecule favors homogeneous deposition with no separate phase formation of pure $\mathrm{Cu}^{\circ}$ and $\mathrm{Ni}^{0}$.

The essentially constant percentage distribution of nickel as $\mathrm{Ni}(\mathrm{OH})_{2}$ in the films suggests that this product arises from the reduction of the water coordinated to the nickel in the complex. Mass balance calculations indicate that oxide in the $\mathrm{Cu}_{2} \mathrm{O}$ and $\mathrm{NiO}$ products originates from the central $\mu_{4}$-oxygen atom in the complexes. Smooth variations of alloy compositions, metal oxide/metal ratios, and film particle sizes indicates that all the electrode processes involve discrete molecules of $\left(\mu_{4-}\right.$ O) (denc) ${ }_{4} \mathrm{Cu}_{4-x} \mathrm{Ni}_{x}\left(\mathrm{H}_{2} \mathrm{O}\right)_{x} \mathrm{Cl}_{6}$

Transmetallation of $\left(\mu_{4}-\mathrm{O}\right) \mathrm{L}_{4} \mathrm{Cu}_{4} \mathrm{Cl}_{6}$ (Eq. 1) with stoichiometric amounts of different transmetallators $M(N S)$ $(\mathrm{M}=\mathrm{Co}, \mathrm{Ni}$, or $\mathrm{Zn}$ ) has the potential of generating a series of complexes with various metal stoichiometries. However, as in $\left(\mu_{4}-\mathrm{O}\right) \mathrm{L}_{4} \mathrm{Cu}_{4-x} \mathrm{Ni}_{x}\left(\mathrm{H}_{2} \mathrm{O}\right)_{x} \mathrm{Cl}_{6}$, the new metal centers introduced by transmetallation often coordinate water during complex isolation. ${ }^{31}$ The present work suggests that electrodeposition of such complexes results in $\mathrm{Mr}(\mathrm{OH})_{2}$ alloy or mixed metal films and metal oxides through combination with the $\mu_{4}$-oxygen. However, oxide formation is not expected for electrodeposition of mixed-metal complexes made from (denc) ${ }_{4} \mathrm{Cu}_{4} \mathrm{Cl}_{3}$, which is known to be transmetallatable and which contains no $\mu_{4}$-oxygen ${ }^{64}$

Because it employs discrete heterotetranuclear molecules, our approach to alloy or mixed metal deposition offers closer experimental control of product composition than is possible with mixtures of homonuclear complexes that have different hydrodynamic and electrochemical 
properties. Among the remaining questions to be addressed are the following. Is there direct electron transfer from the electrode to the metals? Does the DMSO ligand facilitate electron transfer? How do electron transfer and partially reduced complex fragmentation rates vary with precursor composition and structure? How strained are the films and are they isotropic? How does this strain level compare with that found in conventional electrodeposits? What kinetic and other factors determine the compositions, structures, strain, and particle sizes of the films?

The wide range of homologous heterotetranuclear complexes, containing different metals through transmetallation, provides a systematic way to seek answers to such questions and to explore basic electrodeposition mechanisms. We will present the results in subsequent papers.

\section{Acknowledgments}

Acknowledgment is made to the Donors of the Petroleum Research Fund, administered by the American Chemical Society for partial support of this research (S.P.K.), to the National Science Foundation (CHE9256871) (S.P.K.), and to the U.S. Environmental Protection Agency through the Tufts Center for Environmental Management (A.R., S.P.K.). One of us (M.L.A.) is grateful to Gazi University for granting a leave of absence to undertake this work.

Manuscript submitted Feb. 23, 1995; revised manuscript received June 2, 1995.

Tufts University assisted in meeting the publication costs of this article.

\section{REFERENCES}

1. Perspectives in Catalysis, J. M. Thomas and K. I. Zamaraev, Editors, Blackwell, Oxford (1992).

2. J. H. Sinfelt, Bimetallic Catalysts, John Wiley \& Sons, New York (1983).

3. K. Vu Quang, E. Chassaing, B. Le Viet, J. P. Celis, and J. R. Roos, Met. Finish., 83, 25 (1985).

4. A. Brenner, Electrodeposition of Alloys, Vol. 1, pp. 558584, Academic Press, New York (1963).

5. S. Trasatti, in Electrochemistry of Novel Materials, J. Lipkowski and P. N. Ross, Editors, VCH Publ., New York (1994).

6. J. Roos, J. P. Celis, C. Buelens, and D. Gordis, in Process Metallurgy, Vol. 3, I. Warren, Editor, Elsevier, Amsterdam (1984).

7. H. D. Hineline and W. B. Cooley, Trans. Am. Electrochem. Soc., 48, 61 (1925).

8. L. E. Stout and C. L. Faust, Trans. Electrochem. Soc., 60, 271 (1931).

9. Y. N. Sadana and T. K. Venkatachalam, Met. Finish., 15 (Aug. 1979).

10. Y. N. Sadana, A. K. Despande, and R. N. Gedye, Surf. Tech., 17, 111 (1982).

11. M. Ishikawa, H. Enomoto, M. Matsuoka, and C. Iwakura, Electrochim. Acta, 39, 2153 (1994).

12. R.Y. Ying, This Journal, 135, 2957 (1988).

13. J. Horkan, I-C. H. Chang, P. C. Andricacos, and E. J. Podlaha, ibid., 138, 411 (1991).

14. J. Crousier and I. J. Isimagbra, J. Appl. Electrochem., 23, 775 (1993).

15. J. A. Bertrand and J. A. Kelley, J. Amer. Chem. Soc., 88, $4746(1966)$

16. J. A. Bertrand, Inorg. Chem., 6, 495 (1967).

17. C. M. Harris and E. Sinn, Inorg. Nucl. Lett., 5, 125 (1969).

18. B. T. Kilbourne and J. D. Dunitz, Inorg., Chim. Acta., 1, 209 (1967).

19. B. D. Bright and J. N. Helle, Acta. Crystallogr., B28, $3436(1972)$

20. M. R. Churchill and B. G. DeBoer, Inorg. Chem., 14, 2502 (1975)

21. H. M. Haendler, Acta. Crystallogr., C46, 2054 (1990).

22. R. C. Dickenson, F. T. Helm, W. A. Baker, T. D. Black, and W. H. Watson, Inorg. Chem., 16, 1530 (1977).

23. F. J. Keij, J. G. Haasnoot, A. J. Oosterling, J. Redijk, C. J. O'Connor, J. H. Zhang, and A. L. Spek, Inorg. Chim. Acta, 181, 185 (1991).

24. M. A. Sayed, A. Ali, G. Davies, S. Larsen, and J. Zubi- eta, ibid., 194, 139 (1992).

25. H. tom Dieck, ibid., 7, 397 (1973).

26. H. L. Felderova, D. Makanova, and G. Dersi, J. Therm. Anal. 37, 2335 (1991).

27. G. Davies, M. A. El-Sayed, and A. El-Toukhy, Chem. Soc. Rev., 101 (1992).

28. K. G. Caulton, G. Davies, and E. M. Holt, Polyhedron, 9, 2319 (1990).

29. A. El-Toukhy, G. Z. Cai, G. Davies, T. Gilbert, K. Onan, and M.Veidis, J. Amer. Chem. Soc., 106, 4596 (1984).

30. S. Al-Shehri, G. Davies, M. A. El-Sayed, and A. ElToukhy, Inorg. Chem., 29, 1198 (1990).

31. A. Abu-Raqabah, G. Davies, M. A. El-Sayed, and A. El-Toukhy, ibid., 28, 1156 (1989).

32. G. Davies, M. A. El-Sayed, A. El-Toukhy, M. Henary, and T. R. Gilbert, ibid., 25, 2373 (1986).

33. G. Davies, B. C. Giessen, and H.-L. Shao, Mater, Lett., 9, 231 (1990).

34. S. P. Kounaves, B. Workie, A. Robbat, and G. Davies, Abstract 565, p. 880, The Electrochemical Society Extended Abstracts, Vol. 93-2, New Orleans, LA, Oct. 10-15, 1993 .

35. C. E. Dubé, S. P. Kounaves, A. Robbat, and B. Workie, Abstract 918 , p. 1406, The Electrochemical Society Extended Abstracts, Vol. 94-1, San Francisco, CA, May 22-27, 1994

36. S. P. Kounaves, A. Robbat, and G. Davies, U.S. Pat. 5,277,789 (1994).

37. B. Workie, C. E. Dubé, M. L. Aksu, S. P. Kounaves, A. Robbat, and G. Davies, J. Electroanal. Chem., Submitted.

38. B. R. Coles, J. Inst. Met., 84, 346 (1956).

39. B. E. Warren, X-Ray Diffraction, Addison-Wesley, Reading, MA (1969).

40. H. P. Klug and L. E. Alexander, X-Ray Diffraction Procedures for Polycrystalline and Amorphous Materials, John Wiley \& Sons, New York (1974).

41. D. A. Shirley, Phys. Rev., 5, 4709 (1972).

42. H. D. Speckmann, S. Haupt, and H. H. Strehblow, Surf. Interface Anal., 11, 148 (1988).

43. C. Jansson and S. Tougaard, J. Vac. Sci. Technol., A12, 2332 (1994).

44. M. A. Burke and J. J. Schreurs, Surf. Interface Anal., 5, 155 (1983).

45. H. Kichinosuke and T. Sato, ibid., 3, 76 (1981).

46. J. E. Fulghum and R.W. Linton, ibid., 13, 186 (1988).

47. Joint Committee on Powder Diffraction Standards, Powder Diffraction File, Set 5, No. 667, Swarthmore, PA.

48. J. E. Castle, Surf. Sci., 68, 583 (1977).

49. T. L. Barr, J. Phys. Chem., 82, 1801 (1978).

50. P. S. Ho, J. E. Lewis, H. S. Wildman, and J. K. Howard, Surf. Sci., 57, 393 (1976).

51. G. Panzner, B. Egert, and H. P. Schmidt, ibid., 151, 400 (1985).

52. K. S. Kim and N. Winograd, ibid., 43, 625 (1974).

53. B. P. Lochel and H. H. Strehblow, This Journal, 131, 713 (1984).

54. C. J. Powell, Surf. Sci., 299/300, 34 (1994).

55. S. Tanuma, C. J. Powell, and D. R. Penn, Surf. Interface Anal., 17, 911 (1991); 20, 77 (1993).

56. C. J. Powell, Electron Spectrosc. Relat. Phenom., 47, 197 (1988)

57. C. J. Powell and M. P. Seah, J. Vac. Sci Technol., A8, 735 (1990).

58. N. A. McIntyre, S. Sunder, D. W. Shoesmith, and F. W. Stanchell, ibid., 18, 714 (1981)

59. J. K. Zehetmair and R. L. Lintvedt, Inorg. Chem., 29, $2201(1990)$

60. C. E. Dubé, S. P. Kounaves, and G. Davies, Unpublished results.

61. E. Chassaing and R. Wiart, Electrochim. Acta, 29, 649 (1984).

62. T. Dickinson, A. F. Povey, and P. M. A. Sherwood; $J$. Chem. Soc., Faraday Trans., 73, 327 (1977).

63. C. Q. Cui and J. Y. Lee, This Journal, 141, 2030 (1994).

64. M. A. El-Sayed, Polyhedron, 11, 1261 (1992).

65. N. S. McIntyre and M. G. Cook, Anal. Chem., 47, 2208 (1975).

66. Handbook of Photoelectron Spectroscopy, PerkinElmer Corp., Eden Prairie, MN (1979).

67. R. B. Diegle, N. R. Sorenson, C. R. Clayton, M. A. Kelfund, and Y. C. Yu, This Journal, 135, 1085 (1988). 